\section{Gilberto Freyre e o tempo-espaço brasileiro: uma crítica ao cronótopo da modernidade*}

\author{
Sergio B. F. Tavolaro**
}

Resumo: O artigo revisita uma das teses que permeiam de ponta a ponta a obra de Gilberto Freyre, a saber, a sociedade brasileira, fruto de formação sui generis, lograva atenuar, quando não resistir, com insuspeita criatividade, às investidas de padrões mentais, comportamentais, estéticos e institucionais estranhos às suas tradições, os quais vinham se insinuando sobre ela de maneira cada vez mais sistemática a partir do século XIX. Importa-me sobremaneira que essa hipótese Ihe servisse para avançar outra de suas ideias-força, qual seja, a de que nossa formação social representava uma modalidade tão diversa quanto bem-sucedida da modernidade. O artigo almeja revisitar tal programa intelectual com o propósito de compreender como esse intérprete mobiliza, ao longo de sua vasta obra, as categorias tempo e espaço, e quais usos, conotações e sentidos emprestados a tais noções mais se sobressaem em seus esforços de interpretação da experiência moderna no Brasil. Por fim, pretendo sondar potenciais contribuições de Freyre para o discurso sociológico da modernidade.

Palavras-chave: Gilberto Freyre, pensamento social brasileiro, modernidade, teoria sociológica.

"A Praça venceu o engenho", assevera Gilberto Freyre em Sobrados e mucambos, mas não sem deixar de nos alertar que tal fenômeno deu-se

[...] quase sempre respeitando nos vencidos umas tantas virtudes e gabolices; procurando imitá-las; às vezes até romantizando-as e exagerando-as nessa imitação de "inferiores" por "superiores" (Freyre, 1996: 30).

Nesta, como em outras de suas celebradas obras, Freyre torna explícita uma hipótese que atravessaria de ponta a ponta seu programa intelectual: a sociedade brasileira, fruto de formação sui generis, lograva atenuar, quando não resistir, com insuspeita criatividade e galhardia, às investidas de padrões mentais, comportamentais, estéticos e institucionais estranhos às suas tradições, padrões que vinham se insinuando sobre ela de maneira cada vez mais sistemática a partir do século XIX, na esteira da escalada hegemônica da Europa ocidental e da América do Norte (Freyre, 1996: 34 e 47). Como bem sabemos, revisitada (por vezes à exaustão) em várias de suas principais obras, tal hipótese servia-Ihe para avançar outra de suas ideias-força, qual seja, a de que nossa formação social representava uma modalidade tão diversa quanto bem-sucedida da modernidade. Aqui, por razões que nosso autor também
Recebido: 27.02.16

Aprovado: 16.11 .16

\author{
* O presente artigo \\ é fruto de pesquisa \\ desenvolvida com \\ apoio do CNPq/Bolsa \\ de Produtividade em \\ Pesquisa. Agradeço \\ as/os pareceristas \\ pela leitura crítica \\ e sugestões, as \\ quais auxiliaram \\ a recalibrar os \\ objetivos e ambições \\ deste trabalho, bem \\ como esclarecer \\ os argumentos \\ defendidos.

** Professor do
Departamento
de Sociologia e
do Programa de
Pós-Graduação
em Sociologia da
Universidade de
Brasília. Bolsista
pesquisador do
CNPq. Doutor em
sociologia pela The
New School for Social
Research (USA).
<sergiotavolaro@
unb.br>. \\ unb.br>.
}


1. Por quadro de referência epistemológico refiro-me tão somente às noções, categorias, códigos, conceitos, esquemas classificatórios e procedimentos de inferência (com ambições científicas ou não) que, como condições de possibilidade cognitiva, poderão ter delimitado os horizontes de imaginação de Freyre acerca da "singularidade brasileira", tanto em suas narrativas históricas como em outras modalidades de trabalho desse intérprete do Brasil. costumava associar às especificidades do espaço tropical, a frenesi moderna ganhava cadência própria, uma temporalidade e um ritmo diversos daqueles que tiveram lugar na "Europa carbonífera e burguesa" (Freyre, 2003).

Passadas várias décadas desde a publicação dos principais trabalhos de Freyre, permanece o interesse na avaliação do legado de sua obra (Kominsky, Lépine \& Peixoto, 2003), do apelo de seus retratos do Brasil no presente (Cardoso, 2013) bem como de "seu lugar na história da teoria social" (Burke \& Pallares-Burke, 2009: 306). O objetivo precípuo do artigo é revisitar seu programa intelectual com o intuito de compreender de que maneiras as categorias tempo e espaço são mobilizadas, e quais usos, conotações e sentidos emprestados a tais noções mais se sobressaem em seus esforços de interpretação da experiência moderna no Brasil. Ainda assim, de uma forma ou de outra, aquelas preocupações acerca do legado e da relevância atual das formulações de Freyre também norteiam minhas investigações: num plano mais geral, interessa-me indagar sobre o quadro de referência epistemológico ${ }^{1}$ a partir do qual emergem suas imagens da (pretensa) singularidade brasileira a fim de identificar ao menos algumas das condições de possibilidade de suas formulações. Por fim, almejo apreciar o alcance de suas proposições à luz de problemas e questões recentes que revolvem o imaginário sociológico da modernidade.

Vale dizer, o destaque aqui conferido ao tempo e ao espaço justifica-se pela centralidade que gozam no próprio imaginário da modernidade. Além de considerados como "dimensões materiais fundamentais da vida humana" (Castells, 1999: 376), quando não "categorias básicas da existência humana" (Harvey, 1995: 202), um e outro revelam-se elementos basilares desse imaginário: certos sentidos conferidos ao tempo e ao espaço ajudam a delimitar os horizontes de cognição e a circunscrever as possibilidades de imaginação a respeito da modernidade (Gumbrecht, 1998; Habermas, 1990; Koselleck, 2006a; Koselleck, 2006b); a partir de ambos, estabelecem-se parâmetros por meio dos quais a experiência moderna é cotejada e contrastada com outras configurações societárias (Bergmann, 1992; Berman, 1986; Giddens, 1991; Gumbrecht, 2010; Gumbrecht, 2015; Harvey, 1995; Luhmann, 1976). Não é de estranhar, pois, que também Freyre tenha devotado tamanha atenção a essas categorias em suas elucubrações a respeito da formação brasileira - cabe lembrar, em seu tempo, quase invariavelmente representada em descompasso com as chamadas "sociedades avançadas do Ocidente". Ora, certas noções de tempo e espaço contribuíram igualmente para delimitar seus horizontes de imaginação e suas narrativas históricas do Brasil e de outras sociedades que lhe serviam de parâmetro para retratar a pretensa "singularidade brasileira". Não por outro motivo, a análise desses problemas pode auxiliar a esclarecer as complexas relações que sua obra entretece com o próprio imaginário da modernidade. 
Em linhas gerais, este não é um problema de todo negligenciado por sua fortuna crítica (Andrade, 2003; Araújo, 1994; Bastos, 2006; Lima, 2013; Santos, 2008; Villas-Bôas, 2003). De uma forma ou de outra, argumenta-se que, para Freyre, haveria no Brasil uma configuração espaço-temporal ímpar, um arranjo tão distinto quanto esta sociedade (Burke \& Pallares-Burke, 2009; Larreta \& Giucci, 2007; Tavolaro, 2013; Villas-Bôas, 2006) - ou seja, na interpretação freyreana, a peculiaridade do arranjo espaço-temporal brasileiro caminharia pari passu com a propalada singularidade de sua sociedade. Embora, de fato, esse me pareça um ponto de partida analítico promissor, desejo acrescentar alguns elementos a essa interpretação, os quais codifico em três hipóteses de trabalho interligadas. Primeiramente, em seus esforços para delinear as especificidades do tempo-espaço brasileiro, Freyre caminha quase sempre no sentido de atribuir substância a ambas as noções, conferindo-Ihes predicados a seu ver inextrincavelmente vinculados a contextos e situações particulares não por acaso, com certa frequência associados de maneira exclusiva ao trópico. Ao assim fazê-lo, de um só golpe, se afasta de acepções neutras, abstratas e gerais do tempo-espaço e exclui por completo a possibilidade da mera replicação e/ou transposição imediata destas para o cenário brasileiro. Em segundo lugar, se é verdade que, conforme alguns de seus analistas já tiveram oportunidade de sugerir, Freyre reclama para a sociedade brasileira o estatuto de configuração moderna sui generis, também com o intuito de desconstruir o estigma de incompletude que a maculava (Burke \& Pallares-Burke, 2009; Larreta \& Gucci, 2007; Souza, 2000; Villas-Bôas, 2003), na mesma medida, parece-me que o autor ambiciona retratar a experiência espaço-temporal dessa sociedade não como um ensaio malsucedido, imperfeito ou incompleto do cronótopo ${ }^{2}$ da modernidade, mas, de outro modo, como um arranjo moderno dentre outros, alternativo àquele que, sob a hegemonia de algumas poucas sociedades, ascendia à posição modelar no cenário contemporâneo.

Em terceiro lugar, ao invés de adstritos à controvérsia acerca do estatuto moderno (ou pseudomoderno) da sociedade brasileira, esses engajamentos críticos de Freyre tocam em questões igualmente caras a debates contemporâneos em torno do discurso sociológico da modernidade. Parece-me que, ao desafiar o privilégio epistemológico da constelação espaço-temporal que, a seu ver, era característica da modernidade cristalizada na Europa setentrional e na América do Norte, suas formulações oferecem insights para ao menos dois problemas de reflexão que atualmente revolvem esse discurso: (a) a indagação das pretensões universalistas de seus conceitos e categorias e, ato contínuo, a problematização das insinuações prescritivas que, assentadas sobre tais referências supostamente universais, projetam-se sobre configurações modernas não modelares; e (b) a elaboração de ferramentas que habilitem esse discurso sociológico a codificar contextos societários não modelares sem cair presa daquelas pretensões e insinuações supracitadas. Ou seja, malgrado

2. Mikhail Bakhtin emprega o termo cronotopo ("tempoespaço") para referirse à "interligação fundamental das relações temporais e espaciais, artisticamente assimiladas em literatura" (Bakhtin, 1988: 211). No presente artigo, nos passos de Hans U. Gumbrecht (1998; 2015), emprego esta expressão com uma conotação mais ampla, de modo a torná-la aproveitável também para a análise sociológica: compreendo cronótopos como configurações tempo-espaciais, bem como construções conceituais e simbólicas a seu respeito, articuladas a experiências sociais historicamente situadas. 
3. A título de ilustração, ao cotejar as obras Casagrande \& senzala e Nordeste, Burke e Pallares-Burke (2009: 202-203) sustentam que é apenas na segunda que a paisagem torna-se um "personagem do drama", na mesma medida em que se passa a conferir "ênfase considerável aos aspectos negativos da economia e da sociedade do Nordeste." Jessé Souza (2000: 210-212), por sua vez, identifica o que denomina de "torção" nos escritos, obras e trabalhos "da maturidade" de Freyre em relação àqueles "da juventude" do autor (destacandose, nesse último caso, Casa-grande \& senzala e Sobrados e mucambos), algo que Souza associa a motivações políticas ou geopolíticas.

Mas note-se que, ainda conforme suas sugestões, tal "torção" jamais chega a constituir um "corte epistemológico" na obra de Freyre (Souza, 2000: 212).

4. Isso não nos obriga, é claro, a tomá-la como uma "formação discursiva", nos moldes propostos por Foucault.

5. Vale dizer, apesar de tomá-la como um dado importante de pesquisa, o artigo não se satisfaz com a retórica do próprio o fato de, na grande maioria das vezes, alimentar a imagem da brasileira como uma configuração social sem paralelo, e conquanto tenha adotado variáveis explicativas hoje quase completamente deslegitimadas pelo discurso sociológico (Tavolaro, 2016) - o que, a princípio, não faria outra coisa senão confirmar o provincianismo de seu pensamento, ancorado em uma episteme datada, além de animado por um rol de questões obsoleto e/ou circunscrito a características (supostamente) essenciais e irredutíveis à sua própria sociedade -, ao menos algumas das proposições interpretativas de Freyre parecem contribuir para agendas de reflexão atuais que buscam interpelar criticamente o discurso sociológico da modernidade e ajustá-lo à luz de novas preocupações e problemas.

Por fim, uma breve nota metodológica para esclarecer as escolhas e os alcances do artigo - e, é claro, também suas limitações: sirvo-me aqui de diferentes obras de Freyre, produzidas no decorrer de sua longa vida intelectual. É óbvio que essa produção, considerada em sua totalidade, não permaneceu imune a mudanças de ênfase, seja por motivos estritamente "textuais" (desdobramentos "internos" à própria obra) seja por aspectos "contextuais" (políticos, geopolíticos, institucionais, interpessoais etc.), por assim dizer (Buke \& Pallares-Burke, 2009; Kominsky, Lépine \& Peixoto, 2003; Larreta \& Gucci, 2007; Pallares-Burke, 2005; Souza, 2000)³. Ainda assim, tratando-se de uma figura pública sabidamente presunçosa de suas próprias ambiguidades e contradições (Freyre, 1968), talvez não deixe de causar certa surpresa a expressiva permanência, regularidade e continuidade de um conjunto notável de interesses, imagens e noções acerca do Brasil na ampla dispersão da obra de Freyre ${ }^{4}$. Ora, muito embora de modo algum desconsidere a relevância de investigações que explorem as eventuais "influências contextuais" sobre essa obra ou mesmo os "significados contextuais irredutíveis" de algumas de suas formulações, a opção analítica do presente artigo é, por sua "dimensão textual", condizente com os problemas e as preocupações estritas que orientam e circunscrevem prioritariamente este trabalho. Por outro lado, apesar de também considerar relevantes pesquisas movidas pelo interesse de identificar mudanças de ênfase ou de sentido nas noções empregadas pelo autor, o presente trabalho pretende-se um esforço analítico de ideias, conceitos e imagens cujas conotações e sentidos, ao cabo da pesquisa que informou o artigo, revelam grau expressivo de regularidade ${ }^{5}$ - caso, justamente, de certas acepções conferidas às noções de tempo e espaço bem como de visões da sociedade brasileira às quais aquelas noções mostram-se fortemente associadas ${ }^{6}$. Por fim, devo observar que endosso as avaliações que tendem a conferir centralidade às célebres obras de Freyre publicadas nos anos 1930 (Araújo, 1994; Bastos, 2006; Larreta \& Gucci, 2007; Souza, 2000). A meu ver, também no tocante às questões, temas e noções aqui contemplados, essa produção deixou marcas definitivas em momentos posteriores, contribuindo para as continuidades e regularidades que tanto interessam ao artigo. 
Ao mesmo tempo, porém, entendo que a fatura da década de 1930 de modo algum esgota ou sintetiza a agenda intelectual de toda sua vida.

\section{II}

Bem sabemos que a recepção da fatura freyreana já experimentou umas tantas oscilações, por motivos tão diversos quanto as questões contempladas por sua vasta obra: abundam, por exemplo, indagações acerca das controversas conotações político-ideológicas de suas proposições; não menos frequentes são trabalhos dedicados à análise de suas visões do Brasil, acompanhados ou não da avaliação dos impactos continuados de sua empresa interpretativa (seja dentro dos limites estritos do pensamento social brasileiro ou para além deles). Embora reconheça que essas agendas não sejam de todo excludentes, os objetivos e interesses precípuos deste artigo o aproximam de maneira mais clara de preocupações analíticas com os contornos de seus retratos do Brasil. Nesse sentido, conforme já se observou outrora (Tavolaro, 2016: 213-214), a profusão e variedade de ocasiões em que Gilberto Freyre emprega as categorias tempo e espaço não escaparam à percepção de seus analistas mais recentes. Manuel C. Andrade (2003: 223) fala-nos, mesmo, da "presença permanente" do aspecto "geográfico" na maior parte de seus livros e artigos, ou ainda de uma constante "preocupação com a descrição e análise da paisagem", somada a seu interesse pelas "relações entre o homem e o meio" (Andrade, 2003: 225 e 228-229). Ao mesmo tempo, Freyre é apresentado como responsável por instituir sociologicamente o Nordeste brasileiro, retratado como a região que deu "ao país as raízes de uma nova civilização dos tempos modernos" (Tuna, 2000: 91). Em outro registro, fala-se que, em sua obra mais conhecida, as diferenças raciais aparecem codificadas como produto cultural não só de adaptações climáticas específicas, mas também de aspectos ecológicos particulares (Lehmann, 2008). Elide R. Bastos (2006: 11), por sua vez, sustenta que conquanto as problemáticas do patriarcalismo e da interpenetração de etnias e culturas revelam-se dois dos pilares da "unidade explicativa do pensamento freyreano", uma e outra encontram-se inextrincavelmente associadas ao "trópico". Articuladas entre si, essas três variáveis constituiriam, nessa arquitetura interpretativa, os "marcos definidores da formação nacional" (Bastos, 2006: 81). Aliás, a tomar pela leitura de Ana Carolina Santos (2008: 79), a relevância explicativa do trópico - de acordo com Araújo (1994: 58-59), tratado pelo autor pernambucano como um ambiente repleto de "excessos", graças aos quais condições físicas e geográficas se transfigurariam em padrões culturais singulares, que assim se impregnariam no "conjunto da vida social" - torna explícita a acentuada importância atribuída à região, concebida por Freyre "como um todo harmônico no qual natureza e homem compõem o drama da vida em sua riqueza de detalhes [...]." Não por acaso, ainda conforme a análise de Santos (2008: 79), em sua sociologia regional, nosso autor acerca das continuidades que permeiam suas formulações.

6. Uma vez mais, reconheço a importância e relevância de investigações voltadas aos "aspectos contextuais" que envolveram e pesaram sobre a obra de Freyre, assim como daqueles esforços que buscam descortinar as descontinuidades e eventuais rupturas no universo semântico desse intérprete do Brasil. No entanto, a adição dessas novas preocupações à agenda de pesquisa e reflexão do presente artigo o conduziria para direções muito diversas das metas e objetivos específicos aqui estabelecidos. 
intérprete "seleciona tipos de região que indiquem as relações entre os fatos sociais essenciais e as condições físicas fundamentais associadas àqueles." Vale dizer, na avaliação de Burke e Pallares-Burke (2009), essa atenção aguda ao "elemento ecológico" da experiência social cedo se insinuou nos interesses de Gilberto Freyre, como se pode notar em seu entusiasmo precoce por escritores regionais (tais quais Thomas Hardy, Maurice Barrès e Hermann Sudermann), por questões caras à política regionalista (caso de Charles Maurras), bem como por pensadores que se voltavam à investigação de regiões e de suas ecologias (dentre eles Franz Boas e Roquette-Pinto). Tais leituras teriam sensibilizado Freyre

para o elemento ecológico no trabalho de pensadores que ele encontrou mais tarde, como Patrick Geddes, Lewis Mumford, Radhakamal Mukerjee e Carl Sauer (Burke \& Pallares-Burke, 2008: 269).

Note-se que, conforme essa mesma fortuna crítica, atenção análoga é devotada por Freyre à problemática do tempo. Em verdade, para muitos analistas, ambas as categorias se apresentam claramente imbricadas em suas reflexões de maior impacto. Nesse exato sentido, Bastos (2006: 152) também argumenta que, além de um espaço com qualidades especiais, "o trópico, para Gilberto Freyre, é o locus onde se cruzam o tradicional e o moderno [...]." A expressa valorização das qualidades regionais do Nordeste brasileiro, observada desde seus trabalhos da década de 1920, se ancoraria no apego indisfarçável do autor às tradições de um tempo passado que, embora cada vez mais obnubilado, teimava em fazer-se presente (Almeida, 2003). De maneira algo similar, a propósito do programa de reflexão de Sobrados e mucambos, Ricardo B. Araújo (1994: 109) entende que naquela obra, a passagem do tempo é percebida e estudada de forma "espacializada", isto é, "através das modificações sofridas pela arquitetura e pelas formas de sociabilidade doméstica da cultura brasileira." Ou seja, conquanto Freyre, desde cedo, tenha se encantado pelas qualidades particulares de regiões específicas - sendo o Nordeste brasileiro notoriamente o foco prioritário de suas elucubrações - ante o desafio de compreender a emergência bem-sucedida de uma civilização moderna nos trópicos (Larreta \& Giucci, 2007), também de maneira prematura nosso intérprete teria sido tocado por questões relativas ao tempo. É sintomático que, conforme alertam Burke e Pallares-Burke (2009: 271), o ainda jovem Gilberto, estudante da Universidade de Columbia, sob a influência do mestre Franklin Giddings, anotara em sua dissertação de mestrado "a coexistência de diferentes tempos no Brasil do século XIX" - impressão, aliás, que jamais o abandonaria. Não menos importante, em meio às suas recorrentes imersões no passado brasileiro, quase sempre preocupado com a "reconquista europeia" que a partir do século XIX, a seu ver, abateu-se sobre nossa sociedade de maneira cada vez mais sistemática e intensa (Araújo, 1994: 137), Freyre teria se empenhado em avaliar as "perdas e a sobrevi- 
vência do tradicional face ao moderno" (Bastos, 2006: 176). O saldo final seria uma interpretação da formação brasileira "em flagrante oposição às obras que se baseiam nas concepções moderna e progressista de tempo [...]" (Villas-Bôas, 2006: 49).

À luz desses insights iniciais, gostaria de indagar a obra de Freyre de um ângulo que não me parece deliberada e enfaticamente adotado por essa fortuna, a saber, a partir do tratamento articulado de três problemas analíticos relacionados aos usos e sentidos conferidos às categorias tempo e espaço:

1. como condições de possibilidade básicas para suas imagens da experiência moderna no Brasil;

2. como pontos de apoio para seus engajamentos críticos e propositivos com o imaginário da modernidade, amplamente considerado; por fim,

3. como eventuais contribuições para certa agenda recente que vem mobilizando teorizações sociológicas a respeito da modernidade.

Antes, porém, devo chamar atenção para dois aspectos acerca do lugar e da importância dessas categorias na fatura freyreana:

a. mais do que um simples pano de fundo passivo sobre o qual se encenam as relações sociais, ou para além de meras variáveis dependentes de fenômenos sociais específicos, ambas as categorias assumem muitas vezes posição protagonista e ativa em seus esforços interpretativos, capazes de condicionar, quando não de moldar a ordem social brasileira, sua dinâmica bem como o comportamento de seus agentes. Daí a frequente atenção de Freyre aos predicados físico-naturais do trópico americano e à temporalidade que julgava característica desse espaço - esta, da mesma maneira que aqueles, concebida não só como resultado, mas também como elemento propulsor da singularidade brasileira. Além disso, é preciso também reconhecer que

b. ao invés de categorias cognitivas neutras mobilizadas com o propósito único de decifrar o social, tempo e espaço aparecem, em suas obras, impregnadas de juízos de valor: de fato, abundam considerações valorativas - ético-morais assim como estético-expressivas - a respeito de aspectos por ele atribuídos a diferentes configurações espaço-temporais (do Brasil e de outros contextos societários).

Isso posto, cabe enfim a indagação: de que maneiras as noções de tempo e espaço empregadas por Freyre ajudam a delimitar suas formulações a respeito da experiência societal brasileira e seu lugar na modernidade? 
Certa feita, Gilberto Freyre argumentou que o ponto "sempre importante" a se considerar era o fato de o Brasil ser

um país tão essencialmente tropical em sua situação física - na sua situação física quase total - que sua agricultura, pecuária, arquitetura, hábitos alimentares, maneira de trajar e hábitos recreativos têm que corresponder a essa situação, tão diferente da europeia (Freyre, 2000b: 51).

Não por outra razão, para ele,

em lugar de macaquear a maneira europeia de viver e vestir, os hábitos alimentares, a arquitetura (Freyre, 2000b: 51) [e tantos outros aspectos, parecia-Ihe que aquilo que tornava] o Brasil moderno particularmente interessante como experiência social de civilização moderna em um ambiente não europeu é o fato de que os brasileiros conseguiram, vencendo grandes dificuldades, desenvolver certo número de valores essencialmente europeus num am-

7. É certo que essas não foram, de modo algum, as únicas influências intelectuais "estrangeiras" de Freyre. A respeito do impacto de duas gerações de intelectuais espanhóis (a de 1898 e a de 1914) sobre o autor, enfeixando suas discussões acerca das relações tradição/ modernidade, Oriente/Ocidente, europeísmo/não europeísmo, ver Bastos (1998). Quanto ao legado de pensadores latino-americanos sobre sua produção, ver Crespo (2003). Por fim, no tocante às influências românticas britânicas sofridas por Freyre desde o início de sua formação intelectual, ver Pallares-Burke (2005). biente essencialmente não europeu (Freyre, 2000b: 51).

Ora, é em tom de denúncia aos "estrangeirismos" e às "roupagens exóticas" que teriam se assenhoreado da República, que o quase mítico Manifesto regionalista proclama que "de regiões é que o Brasil, sociologicamente, é feito, desde os seus primeiros dias. Regiões naturais a que se sobrepuseram regiões sociais" (Freyre, 1976: 31-32, grifos meus). Tais regiões, segundo o mesmo manifesto, deveriam ser concebidas como "modos de ser", ou ainda "formas de expressão" características da realidade nacional brasileira (Freyre, 1976: 30-31). Daí a exortação ao estudo prioritariamente regional da "cultura brasileira, do mesmo modo que a natureza; o homem da mesma forma que a paisagem" (Freyre, 1976: 33). A bem da verdade, reflexões análogas já o haviam ocupado antes. É sugestivo que em sua "Introdução" à obra Região e tradição, ao referir-se ao movimento regionalista do Nordeste como uma espécie de neorromantismo de cunho realista, Freyre tenha tecido elogiosas considerações aos "velhos românticos alemães" (Justus Moses, Herder, Jakob Grimm, Ranke) por sua oposição à certa "filosofia de universalidade estática", em favor do reconhecimento nos "fatos do desenvolvimento e da atividade humana [...] daquela variedade no tempo e no espaço" (Freyre, 1941: 37-38). Note-se, em especial, o destaque do autor à recusa daqueles pensadores à

cristalização em leis universais de conduta e em formas universais de expressão, do que é, por natureza, e em grande parte, vario, flexível, inconstante no tempo e diverso no espaço (Freyre, 1941: 37-38). 
Ora, em seu entendimento, mesmo admitida a existência do geral e do universal, ainda assim, um e outro seriam "em grande parte [...] resíduo do regional e do temporal" (Freyre, 1941: 37-38).

Seria incorrer em erro, contudo, inferir que tal opção metodológica pelo espaço regional inevitavelmente conduzia Freyre a estreitar seus horizontes de investigação ou mesmo a apequenar suas ambições analíticas. Já de início, interessava-lhe trazer à luz formas peculiares de existência social que, a despeito de espacialmente circunscritas, se lhe revelavam por demais importantes para serem simplesmente ignoradas. Havia, no entanto, outras questões em jogo que acabavam por potencializar o escopo e alcance de suas interlocuções: por um lado, a investigação dos predicados físicos e culturais das regiões constituía-se em um meio promissor para abordar a própria formação social brasileira e suas alardeadas originalidades no contexto mundial; por outro, tão ou mais importante que isso, a eleição metodológica da região, associada ao resgate e à valorização veementes da tradição, aparamentava-o, na mesma medida, a interpelar a própria modernidade e, ato contínuo, o amplo e variado campo discursivo a seu respeito. Não admira, pois, que suas críticas à modernização, ao ocidentalismo "que vê em tudo o que é antigo ou oriental um arcaísmo a ser abandonado" (Freyre, 1976: 41), à sua temporalidade própria tanto quanto a seus efeitos desvirtuadores das originalidades brasileiras estivessem quase sempre presentes nos trabalhos em que se propôs destacar as criações caracteristicamente regionais do Nordeste. Nesses casos, é patente o sentimento de perda em relatos que registram, com rara nitidez, os impactos da passagem do tempo na esteira da crescente europeização experimentada pela sociedade brasileira, seja na paisagem rural (Freyre, 1941: 107; 2015: 105), seja na urbana (Freyre, 1941: 108), ou mesmo na social (Freyre, 1941: 118, 123, 125, 139, 142, 152, 153, 162, 163; 2015: 104). A certa altura, Freyre chega mesmo a observar que

comparando o Nordeste de 1825 com o de 1925 tem-se quase a impressão de dois países diversos. A própria paisagem, o próprio físico da região, alterou-se nestes cem anos. É outra a sua crosta. Outra a fisionomia (Freyre, 1941: 107).

Ao menos dois aspectos sobressaem-se nessas formulações, ambos expressivos dos usos e sentidos que o autor confere às noções de tempo e espaço. Primeiramente, no tocante à dosagem diversidades regionais/uniformidade nacional, vale observar que Freyre não via qualquer contradição no fato de seus esforços sociológicos de interpretação da formação e do ethos nacional brasileiros serem conduzidos a partir de "uma simplificação aparentemente arbitrária" - isto é, sua consideração por meio 


\begin{abstract}
de sua mais antiga estabilização agrária: a que se verificou na parte setentrional do país, estendendo-se da Bahia ao Maranhão e tendo em Pernambuco o seu primeiro reduto de sistema familial de economia e de organização social e o Rio de Janeiro como sub-região sociológica desgarrada do maciço setentrional apenas geograficamente (Freyre, 1968: 62-63).
\end{abstract}

O autor dizia-se atento, sim, aos "vários começos" da formação dessa sociedade, ergo às suas descontinuidades espaciais e temporais (Freyre, 1996 [1949/1961]: LVIII), "do extremo Norte ao extremo Sul". Mas, a seu ver, tratando-se tão somente de variações "de substância", as diversas regiões do Brasil seriam atravessadas por certa "unicidade sociológica de forma e de processo", conforme se poderia inferir pela replicação "em áreas e em espaços diversos" da "organização mais ou menos patriarcal ou tutelar" (familiar, econômica, política e de sociabilidade, amplamente considerada), da "monocultura", do "latifúndio" e do "trabalho escravo ou servil" (Freyre, 1996: LVIII). Daí não Ihe parecer de modo algum contraditório abordar a formação brasileira por meio da investigação prioritária da região do Nordeste canavieiro, aquele que se alongava "por terras de massapé e por várzeas, do norte da Bahia ao Maranhão" (Freyre, 2004: 37) - dentre outras razões (Freyre, 1976: 34; 1996: LXXXV, LXXVI-LXXVII, LXXXI) porque, admitida a diversidade geográfica do território nacional, permaneceriam expressivas as semelhanças naturais "em tão vasta terra tropical" (Freyre, 1996: LXXIII; 2000b: 31). Para o autor, nessa terra, do contato simbiótico de portugueses "com a natureza, com ambiente e com populações e culturas tropicais" (Freyre, 1968: 86-87), vinha se consolidando "um tipo moderno de cultura mista ou simbiótica - eurotropical" (Freyre, 1968: 87), a seu ver, algo verdadeiramente sem paralelo no concerto mundial.

Um segundo aspecto fundamental nas formulações de Freyre que gostaria de salientar diz respeito à interlocução explícita que o autor estabelece entre as ancoragens espaço-temporais regionais e brasileira e o imaginário da modernidade: uma vez mais apoiado sobre as especificidades societárias associadas a tais ancoragens, Freyre posiciona-se de maneira deliberada em relação a esse imaginário. Conforme anteriormente sugerido, ao invés de confirmar o provincianismo daqueles contextos (regionais e nacional), bem como o alcance supostamente limitado de suas formulações acerca da formação brasileira, Freyre servia-se de tais especificidades para desafiar certas imagens renitentes da experiência moderna, interpelando-as de maneira algo contraintuitiva. Nesse exato sentido, cabe notar que a eleição da região nordestina à posição de principal responsável por "dar à cultura e à civilização brasileira autenticidade e originalidade" (Freyre, 1976: 35-36) - "a parte, sob mais de um aspecto, mais brasileira do Brasil" (Freyre, 1941: 193-194) - fazia-se acompanhar de advertências ruidosas: o resultado quase certo do abandono das tradições regionais 
em favor da "novidade estrangeira" (Freyre, 1976: 33-34) seria a descaracterização quando não o total desvanecimento de criações detentoras de valores (regionais e, por extensão, brasileiros) outrora docemente harmonizadas "com o clima, com as águas, com as cores, com a natureza" dos trópicos (Freyre, 1976: 37). Ou seja, para o autor, em vez de universais e/ou atemporais, o valor dessas criações - das quais as habitações, a culinária, as vestimentas bem como o desenho urbano de algumas cidades do Nordeste seriam exemplos primorosos (Freyre, 1941; 1976) - adviria em boa medida do fato de estarem doce e graciosamente adaptadas às particularidades do espaço regional e de sua natureza (seu ar, seu calor, sua paisagem, seus recursos, sua fauna e flora e sua luz peculiares). Mas esse tipo de argumento não restringia o alcance pretendido para suas críticas. Se, por um lado, Freyre almejava trazer às claras os alicerces mais essenciais do real valor daqueles predicados sociais e naturais observados no Brasil, por outro, tratava-se também de revelar os limites das ambições universalistas de certas formas de viver e pensar.

Por tudo isso, não surpreende a preocupação do autor em descrever o meio natural e a configuração temporal em que, a seu ver, vicejava essa civilização moderna peculiar ${ }^{8}$. Conforme almejo frisar na próxima seção, importava-lhe investigar não só como os agentes da formação brasileira vinham forjando uma nova cultura e uma experiência social original em sintonia fina com os predicados e atributos físicos do espaço e do tempo dos trópicos; outrossim, era desejo de Freyre revelar ainda suas influências e contribuições para sua emergência.

\section{IV}

Não se pode, é claro, subestimar as passagens em que Freyre reclama da "preponderância das causas econômicas e sociais [...] sobre as influências de raça e clima" nos processos que desaguariam na formação brasileira (Freyre, 2000a: 428-429). Ocorre que proposições como essa não o impediam também de argumentar que "a civilização trazida da Europa para o Brasil [...] adquiriu aspectos regionais diversos" tão logo viu-se ante o desafio de se adaptar "a diferentes situações ecológicas" (Freyre, 1996: XXXIII). Mas observe-se que, a contrapelo das imagens corriqueiras de uma natureza tão encantadora e exuberante quanto entorpecente dos espíritos e ações - de resto, alimentadas por vários dos intérpretes do Brasil que o haviam precedido $^{9}$-, Freyre ponderava que,

[s]e é certo que nos países de clima quente o homem pode viver sem esforço de abundância de produtos espontâneos, convém, por outro lado, não esquecer que igualmente exuberante são, nesses países, as formas perniciosas de vida vegetal e animal, inimigas

8. A seu ver, ao termo da "disseminação de formas altas de civilização em tão vasta terra tropical", vinha emergindo nada mais nada menos que a "primeira grande civilização moderna nos trópicos" (Freyre, 1996: LXXIII).

9. Nesse particular, apenas a título de ilustração, talvez baste recobrar os retratos do país delineados por Silvio Romero (2001) e, posteriormente, por Paulo Prado (2012). 
de toda cultura agrícola organizada e de todo trabalho regular e sistemático (Freyre, 2000a: 90).

Tal a magnitude dos esforços exigidos à colonização nos trópicos que somente agentes predispostos àquele meio poderiam consumá-la da maneira bem-sucedida como o fizeram. Nesse particular, a contribuição do elemento indígena, notável "pelo seu minucioso conhecimento da flora e da fauna do país" (Freyre, 2015: 143), teria se revelado fundamental visto que já haveria, entre os nativos

desta parte do continente, como entre os povos primitivos em geral, certa fraternidade entre o homem e o animal, certo hibridismo mesmo nas relações entre os dois (Freyre, 2000a: 170).

Fundamental, também, havia sido a "predisposição como que biológica e psíquica para a vida nos trópicos" demonstrada pelos negros africanos. Haveria concorrido para isso "sua maior fertilidade nas regiões quentes. Seu gosto de Sol. Sua energia fresca e nova em contato com a floresta tropical" (Freyre, 2000a: 346; 2004: 88-89; 2015: 126). Por fim, a ambos teria se somado a "aclimatabilidade" do português "ao contato vitorioso com os trópicos" (Freyre, 2000a: 85), igualmente por "felizes predisposições de raça, de mesologia e de cultura" (Freyre, 2000a: 87; 2000b); haveria, na verdade, certa obsessão dos portugueses "pela residência nos trópicos, pela adoção de valores tropicais, pela união com mulheres tropicais" (Freyre, 2010: 236). Ora, de acordo com Freyre, como resultado dessas "felizes predisposições" (biológicas, psíquicas e culturais) ao meio tropical,

tomaram também com o tempo essas raças, cores regionais diversas conforme as condições físicas da terra, de solo e de configuração de paisagem ou de clima e naturais, de meio social (Freyre, 1996: LIII, grifos meus)

Tamanha cumplicidade dos agentes da colonização com essa natureza que, em certos lugares da região nordestina, chegava-se às raias de algumas pessoas se sentirem íntimas de animais, plantas e árvores, como se esses últimos fossem "gente de casa", "uma quase pessoa", "quase pessoa de casa", para além de meros "restos brutos e insensíveis de mata ou de floresta" (Freyre, 1976: 67 a 70).

Sem deixar, pois, de admitir as inúmeras adversidades do trópico para uma vida sistemática e ordenada em conformidade com padrões europeus (Freyre, 2004: 88; 2000a: 89-90), está claro que Freyre divergia daqueles para quem, em última instância, o espaço tropical impunha obstáculos intransponíveis à formação de sociedades superiores. Ao invés disso, tratava de acentuar as próprias contribuições 
desse espaço para a emergência de uma nova configuração moderna, em diversos aspectos inédita, "obra criadora e original [dos portugueses], a que não pode aspirar nem a dos ingleses na América do Norte nem a dos espanhóis na Argentina" (Freyre, 2000a: 89). É nesse contexto argumentativo que se pode compreender, por exemplo, a celebração do massapê - "terra doce ainda hoje", amaciadora de homens e instituições - como agente conformador de primeira linha, moldando uma experiência societária erguida sobre a cultura da cana de açúcar (Freyre, 2004: 47), a partir de "condições particularmente favoráveis de solo, de atmosfera, de situação geográfica" (Freyre, 2004: 48).

Freyre é enfático ao defender que fatores ambientais dessa sorte ajudaram a forjar padrões comportamentais, hábitos, valores, instituições, referências ético-morais e laços sociais diversos dos europeus - padrões, valores, instituições e referências mais fluidos, plásticos e maleáveis do que os "puramente europeus", isto é, do que aqueles típicos da Europa setentrional, "protestante, burguesa e carbonífera" (ver, por exemplo, Freyre, 2000b: 53). Estaríamos, pois, diante de um meio físico mais quente, colorido e vivaz que o norte-europeu, convidativo a relações sociais mais frouxas, intensas, ardentes, lúbricas e licenciosas (Freyre, 2000b: 53). É verdade que, em sua avaliação, tal fenômeno, em suas linhas gerais, não fora de todo estranho ao português, ele próprio cultural e biologicamente moldado sob a influência de

um ar quente, oleoso, amolecendo nas instituições e nas formas de cultura as durezas germânicas; corrompendo a rigidez moral e doutrinária da Igreja medieval [...] (Freyre, 2000a: 80).

Todavia, o contato com o trópico americano não fizera outra coisa senão acentuar ainda mais esses traços (Freyre, 2000b: 40) - dos quais a flexibilização da moral sexual e o consequente "colapso da moral católica" (Freyre, 2000a: 179) talvez fossem duas dentre suas manifestações mais visíveis.

Note-se que, na equação interpretativa do autor, a essas especificidades espaciais se entrelaçaria uma configuração temporal não menos peculiar: um "tempo impregnado ecologicamente de trópico" (Freyre, 2000b: 32). A contrapelo, pois, de conotações abstratas e universais emprestadas à categoria tempo (Anderson, 1991; Giddens, 1991; Harvey, 1995), Freyre preferia chamar a atenção para suas consideráveis variações, "de regiões para regiões, quer de um continente a outro, quer dentro de um país" (Freyre, 1975a: XLVI); tais variações se fariam exprimir "em diversas manifestações, de existência, de convivência e de cultura." (Freyre, 1975a: XLVI ${ }^{10}$. Conforme sugerido alhures (Tavolaro, 2016), essa recusa expressa a

10. Propõe Freyre que "quem estuda ou considera o problema de relações interregionais dentro de um país [...] não pode alhear-se ao fato de que são também relações entre tempos" (Freyre, 1975a: XLVI). 
qualquer noção esvaziada e geral de tempo, alheia a peculiaridades espacialmente condicionadas, levava-o, ainda, a propor que, seja nas relações sociedade/cultura seja no caso de indivíduos isoladamente contemplados, não existiria "um tempo só vivido de modo unilinear; e sim vários tempos, variamente, contraditoriamente" (Freyre, 1973: 109-110) - de acordo com Freyre, "tempos que se cruzam e se confundem, quer na vivência, quer na memória de qualquer um de nós [...]" (Freyre, 1973: 110).

11. Freyre (2000b: 31) afirma que "o homem é tempo tanto quanto é espaço: sofre pressões de tempo quanto de espaço que o condicionam, embora não determinem seu ser [...]."

Ora, porquanto tempo e espaço, a seu ver, jamais pudessem ser desassociados em experiência humana alguma ${ }^{11}$, o interesse prioritário do autor estava em desvelar seus vínculos e manifestações encontrados nas modernas configurações societárias erguidas nos trópicos. Ora, como já se chamou atenção antes (Tavolaro, 2016: 212226), parecia-lhe que, mais do que outras, as populações localizadas em espaços tropicais ou em seus arredores demonstravam falta de interesse por "rigores na contagem de tempo, só atendendo aos extremos de chuva e sol correspondendo a necessidades de alimentação." (Freyre, 1975a: xxxIII) Nada mais distante, portanto, que a configuração temporal comumente atribuída à "modernidade anglo-saxônica": enquanto nesta prevaleceria certa sacralização do "tempo cronométrico" (Freyre, 1973: 25), "com o culto quase místico dos minutos e até dos segundos, devido ao seu valor prático e comercial" (Freyre, 2000b: 264-265), entre as "civilizações e culturas orientais, africanas e ameríndias", predominaria um tipo de atitude "do homem para com o tempo [...] grandemente afetada pelo mito, a religião e o folclore" (Freyre, 1975a: 10) - também por isso estranha àquela visão científica, evolucionista ou progressiva de tempo tornada hegemônica desde a Revolução Comercial (Freyre, 1975a).

Diante do exposto, fosse nosso desejo compreender a sociedade brasileira contemporânea, fruto do sucesso em certa medida inusitado de colonizadores europeus em espaços tropicais, precisaríamos, em primeiro lugar, considerar a predisposição demonstrada pelos ibéricos (e, por conseguinte, por portugueses) à temporalidade própria dos trópicos. Isso porque, "se houve um tempo hispânico", capaz de condicionar o comportamento de hispânicos ou ibéricos no continente americano e em outras partes do globo, "esse tempo não morreu com as descobertas hispânicas de novas terras [...], porém permanece entre sociedades neo-hispânicas em desenvolvimento nesses espaços [...]" (Freyre, 1975a: XLVIII-XLIX). Note-se que, a seu ver, "até certo ponto", aquela predisposição decorria da própria "semelhança entre sentidos de tempo dos hispanos e dos não europeus", responsável por facilitar-Ihes a maior integração, em comparação com os norte-europeus, nos trópicos (Freyre, 1975a: XXXIII). Ora, também em contraste com a ética calvinista impregnada em norte-europeus e norte-americanos, uma ética 
"excessivamente glorificadora do contínuo, do incessante trabalho humano", essa "noção hispânica de tempo" implicava fazer "do ócio um tempo digno de ser vivido criadoramente" (Freyre, 1975a: XXXVI) - ou seja,

não tanto um tempo dedicado religiosamente ao trabalho constante [...], mas um tempo em que o trabalho e o descanso alternavam muitas vezes, entre esforço e dança, com numerosos dias santos e de festa (Freyre, 1975a: 8-9).

O próprio fato de, segundo Freyre, portugueses e espanhóis jamais terem sublinhado em suas relações com povos não europeus uma condição de "povo progressivo" adviria de uma situação claramente distinta daquela com frequência associada à modernidade da Europa setentrional: a saber, que eles nunca atingiram "o que alguns europeus passaram a considerar o tempo social perfeito - o rápido ou o veloz ou o cronometricamente regulado em vários setores" (Freyre, 1975a: 8). Também por esse motivo,

não repeliram como os norte-europeus, quaisquer valores ou técnicas dos não europeus, considerando-os para eles, os norte-europeus, sempre arcaicos e de não europeus, seus supostos inferiores (Freyre, 1975a: 8).

Ou seja, para os hispanos, "como para povos não europeus, em geral", não existiria "fatalidade no Progresso nem na chamada Evolução transposta do plano biológico ao sociológico" (Freyre, 1975a: 60).

Também à diferença do "ritmo constantemente progressivo" instituído desde a Revolução Comercial europeia, o "tempo hispânico" se mostraria "tríbio" em sua constituição mais íntima, isto é, "uma fusão de passado, presente e futuro" (Freyre, 1975a: 8-9). Tal expressão, um empréstimo a Unamuno e Ortega y Gasset, servia ao autor de Tempo morto e outros tempos para acentuar um quadro temporal fluido e infenso à linearidade: aqui, em contraste com o tempo progressivo da Europa do Norte, o passado se faria valer no presente tanto quanto no futuro - este, por sua vez, já prenhe de presente; de maneira análoga, essa mesma noção pretendia referir-se a um quadro em que o presente e o futuro logravam projetar-se sobre o passado, condicionando-o (Freyre, 1975a: 106-107). Daí por que, em concomitância à ausência entre os hispanos da obsessão pela ideia "de ser o futuro sempre melhor que o presente e o presente melhor que o passado" - obsessão, de acordo com Freyre, correspondente "ao mito caracteristicamente europeu de Progresso constante e indefinido" (Freyre, 1975a: 69) -, impunha-se a preferência por "regressos ou finca-pés culturais, sociais, morais que signifiquem 
12. Tal configuração tempo-espacial, assim como aspectos característicos do imaginário que a cercam aparecem retratados, por exemplo, em Anderson (1991), Berman (1986), Giddens (1991), Habermas (1990), Harvey (1995), Koselleck (2006) e Luhmann (1976). De acordo com essa conotação, a abrangência tendencialmente universal do cronótopo da modernidade adviria justamente de seu grau acentuado de abstração, esvaziamento e padronização, os quais o capacitariam a ajustar-se a cenários sociais diversos. resistência a alterações consideradas prejudiciais a interesses de sempre", tudo isso, como se poderia supor, em detrimento de "certos pretendidos progressos" (Freyre, 1975a: 70). Este, tal como aqueles outros traços, também viria a se revelar peça-chave para o sucesso de suas empresas colonizadoras mundo a fora, "a base de entendimento entre os espanhóis ou portugueses e as populações não europeias na Ásia, África e Américas" (Freyre, 1975a: 8-9). Ora, justamente por jamais terem sido adeptos de um "sentido progressivo de tempo" - algo que, em outros contextos, concorreu para alimentar autoimagens de superioridade civilizacional apoiadas sobre a valorização da "rapidez no tempo" e "rapidez nas atividades" (Freyre, 1975a: 10) -, segundo Freyre, os hispanos puderam se beneficiar sobejamente dos predicados culturais e biológicos dos povos não europeus com quem se miscigenaram em espaços tropicais.

Conforme suscitado anteriormente, tais usos, conotações e sentidos conferidos por Freyre às noções de tempo e espaço em seus esforços de interpretação do Brasil poderiam, por princípio, confirmar o escopo e alcance limitados de suas ambições intelectuais: ao se referirem a um cenário social e natural bastante específico, suas formulações em torno dos impactos da modernização sobre a sociedade brasileira não fariam outra coisa senão, em primeiro lugar, $(a)$ reafirmar a propalada inautenticidade dessa experiência moderna, pretensamente capturada por referências cognitivas, normativas, comportamentais, institucionais e estéticas pouco ou nada condizentes com suas singularidades (culturais, biológicas, psíquicas e naturais) mais íntimas; em segundo lugar, (b) poderiam confirmar também a imagem de incompletude dessa mesma experiência em virtude de seus iniludíveis hiatos (culturais, ético-morais, institucionais, econômicos, comportamentais e raciais) em relação às chamadas "sociedades modernas centrais". Ademais, ao fim e ao cabo, $(a)$ e (b) conduziriam Freyre a (c) endossar a posição modelar de certa episteme da modernidade delineada à imagem e semelhança daquelas "sociedades centrais". Parece-me possível, no entanto, abordar essa questão de um ângulo diverso, à luz de ponderações inscritas em seus próprios engajamentos com o imaginário da modernidade: (a) processos de modernização não se fazem acompanhar necessária e inexoravelmente da crescente abstração, dessubstancialização e padronização do tempo e do espaço; (b) o esvaziamento e a padronização do tempo-espaço ${ }^{12}$ não são condições necessárias a toda e qualquer experiência societária organizada em moldes propriamente modernos. Na seção seguinte, ao cotejar as formulações de Freyre com algumas críticas recentes dirigidas ao discurso sociológico da modernidade, almejo avaliar seus eventuais insights nesse debate. 
A que se poderia atribuir o interesse continuado pela obra de Gilberto Freyre? O alcance de suas formulações estaria circunscrito a seus retratos do Brasil? Fernando H. Cardoso credita a "perenidade" do autor, acima de tudo, à força mítica de sua visão de Brasil, "funcionando como um ponto de fuga que, se não retrata a realidade, faz parte dela [...]" (Cardoso, 2013: 134). Burke e Pallares-Burke (2009: 255-256), por sua vez, embora não o tenham como "um grande inventor de novos conceitos", identificam em Freyre a qualidade de expandir o uso daqueles já existentes e de adaptá-los a situações novas; a isso se somaria seu "dom de adotar ideias com um grande futuro num momento em que seu potencial ainda não foi totalmente reconhecido" (Burke e Pallares-Burke, 2009: 307). Ora, se é que, como propõem Burke e Pallares-Burke (2009: 256), algumas das ideias de Freyre continuam "boas para ajudar a pensar", parece-me ser esse o caso de seus engajamentos críticos com o imaginário da modernidade. A meu ver, ao menos em parte, seu apelo continuado no seio do pensamento social brasileiro tem a ver também com o fato de seus retratos do Brasil dialogarem com agendas recentes da sociologia amplamente considerada. A bem da verdade, entendo que as formulações de Freyre fornecem sugestões para alguns dos desafios e questionamentos contemporâneos interpostos ao discurso sociológico da modernidade (Tavolaro, 2013; 2014; 2016). A esse respeito, as análises de Villas-Bôas (2003) acerca da maneira como a "singularidade brasileira" aparece retratada em Casa-grande \& senzala oferecem um ponto de partida promissor.

Vale dizer, Villas-Bôas (2003) também alude à dimensão mítica da obra de Gilberto Freyre, mas prefere situá-la em um quadro intelectual mais amplo: trata-se, para ela, do "mito da ambiguidade do brasileiro", que Freyre e outros pensadores igualmente preocupados com o problema da experiência da modernidade no Brasil teriam ajudado a criar. O autor de Casa-grande \& senzala seria uma das peças do "modelo da harmonia autoritária", coexistente, porém distinto, do "modelo do Brasil do eterno dilema" (Villas-Bôas, 2003: 115-116)13. Por um lado, concordo com Villas-Bôas (2003: 129-130) que o intérprete pernambucano "contraria a visão evolucionista da história que classifica de alto a baixo as culturas e sociedades em imperiais e coloniais, progressistas e retrógradas" (Villas-Bôas, 2003: 123). Mas divirjo de ao menos dois pontos de sua análise. A primeira discordância diz respeito ao estatuto do espaço natural nas formulações de Freyre: a essa altura já se pode inferir que discordo da avaliação conforme a qual a diluição da geografia e da raça no esquema interpretativo de Freyre se faria acompanhar da substituição da terra pela casa-grande patriarcal como o vínculo por excelência da "identidade dos brasileiros" (Villas-Bôas, 2003: 127-128). Ora, as evidências reunidas neste artigo demonstram a importância continuada do espaço natural não somente como

13. Enquanto o primeiro modelo apresentaria "uma disputa sem fim entre valores de uma suposta brasilidade e valores igualitários, universais, modernos", o segundo se apoiaria na ideia de que as "origens históricas e culturais" dos brasileiros constituiriam "um legado positivo para a construção da nação moderna" (Villas-Bôas, 2003: 115). 
14. De maneira análoga, outros analistas chamam atenção para a preocupação de Freyre com o eurocentrismo projetado sobre o Brasil e a América Latina (Crespo, 2003; Larreta \& Giucci, 2007; Schneider, 2012), para seus esforços de "crítica à modernidade ocidental" (Schneider, 2012: 77; Burke \& PallaresBurke, 2009), bem como para sua ambição de elevar a experiência tropical americana à condição de "alternativa civilizatória" à chamada "modernidade carbonífera" (Baggio, 2012: 120; Freitas, 2013; Larreta \& Giucci, 2007; Schneider, 2012). Mas, também nesses casos, o reconhecimento da dimensão crítica das formulações de Freyre não se faz acompanhar de uma consideração explícita de seus eventuais insights propositivos para as dificuldades recentemente apontadas no discurso sociológico da modernidade. uma das âncoras explicativas da "singularidade brasileira" (em combinação com o espaço doméstico, e não em detrimento dele) mas também como ferramenta de primeira ordem em seu engajamento crítico com o imaginário da modernidade. A segunda discordância, em conexão com as questões levantadas na terceira hipótese do artigo, refere-se às eventuais contribuições das formulações de Freyre para certos desafios recentemente apresentados à sociologia da modernidade. Conquanto Villas-Bôas reconheça em Casa-grande \& senzala uma forte reação "ao progresso avassalador", expressão de sua renúncia ao "pressuposto de um tempo universal" (Villas-Bôas, 2003: 123), além de um questionamento à "modernidade no que ela reivindica de monopólio da universalidade e significação" (Villas-Bôas, 2003: 130) - sem dúvida, um ponto de partida promissor -, ela não parece identificar na fatura freyreana contribuições de fato propositivas ao discurso sociológico da modernidade ${ }^{14}$. Visto que, em seu entendimento, não interessa a Freyre "a construção no futuro de uma ordem impessoal e igualitária", e também por não se ocupar "do atraso brasileiro", Villas-Bôas avalia que, embora conduzam "notadamente à construção de uma identidade nacional", ao fim e ao cabo as proposições de Casa-grande \& senzala "não abrem caminhos para a construção da sociedade moderna" (Villas-Bôas, 2003: 131).

De outro modo, quero argumentar que as formulações de Freyre indicam alternativas para alguns dos problemas e das dificuldades recentemente apontados no discurso sociológico da modernidade. Nesse exato sentido, em contraste com a avaliação de Villas-Bôas, parece-me que a obra de Freyre se soma a outras tentativas de abertura de novos caminhos para se pensar a experiência societal moderna. Há um conjunto de abordagens relativamente recentes que, embora bastante distintas em suas fundamentações teóricas tanto quanto em suas ambições programáticas, parecem-me até certo ponto sumarizar alguns dos principais desafios atualmente interpostos a esse discurso sociológico. Refiro-me às agendas de pesquisa e reflexão reunidas sob as designações modernidades múltiplas, modernidade global, pós-colonialidade e decolonialidade do saber/poder (Tavolaro, 2014: 645654). No caso da abordagem das modernidades múltiplas, esforços de avaliação crítica dos pressupostos das teorias da modernização e de suas insinuações prescritivas conduzem seus proponentes à investigação dos desdobramentos sociais e institucionais resultantes do encontro do "programa originário da modernidade" com "premissas culturais, tradições e experiências históricas" distintas das europeias (Eisenstadt, 2000: 1-2; 2010; Göle, 2000; Wittrock, 2000). Já a agenda de pesquisa em torno da noção de modernidade global interpela o imaginário sociológico à luz da expansão da modernidade em escala planetária e da consequente emergência de novos centros societários (vale frisar, "extraeuropeus") - os quais, a seu modo e com suas especificidades históricas, estariam tornando-se referências 
criadoras e modelares da própria modernidade (Schmidt, 2007; 2012; Domingues, 2009). No que diz respeito às reflexões acerca da condição pós-colonial, ao lado da denúncia ao historicismo subjacente ao imaginário da modernidade, busca-se desvelar o provincianismo de categorias, conceitos e noções que, forjados à imagem da experiência histórica europeia, pretendem-se globalmente aplicáveis (Chakrabarty, 2000; Chaterjee, 2008; Hall, 2011). Também nesse caso, tal agenda envolve a formulação de novas narrativas que contemplem o deslocamento "[d]a 'estória' da modernidade capitalista de seu centramento europeu para suas 'periferias' dispersas em todo o globo" (Hall, 2011: 106). Por fim, em relação ao programa da decolonialidade do saber/poder, importa observar, por um lado, a preocupação com as assimetrias de poder simbólico, epistemológico, econômico, cultural e político tidas por constitutivas da própria experiência da modernidade; e, por outro, a atenção a lugares subordinados/subalternos de enunciação, silenciados pela perspectiva hegemônica, unilateral e triunfante da modernidade (Mignolo, 2000; 2005; Dussel, 2005; Quijano, 2005).

Embora se trate de um exercício promissor, foge aos objetivos do artigo a análise em profundidade desses programas de reflexão e/ou das eventuais relações de afinidade e de divergência entre Freyre e cada uma dessas agendas de pesquisa ${ }^{15}$. Admitidas as especificidades irreconciliáveis desses programas, gostaria tão somente de indicar pontos de convergência que, em certa medida, parecem-me sumariar alguns dos principais desafios e críticas recentemente desferidos ao discurso sociológico da modernidade:

1. desafia-se, em primeiro lugar, o estatuto universal de categorias comumente tomadas como parâmetros inequívocos da modernidade; a isso se seguem exercícios de provincianização/descentramento de configurações societárias tidas por originárias daquelas mesmas categorias; no limite, coloca-se em questão a própria posição modelar de tais configurações (pretensamente originárias) no quadro da modernidade;

2. coloca-se em suspeita a real possibilidade e adequação de se reproduzir, pura e simplesmente, em outros contextos espaço-temporais, padrões (institucionais, valorativos, morais, comportamentais, estéticos) modernos forjados à imagem e semelhança das chamadas "sociedades centrais/modelares";

3. indaga-se sobre as assimetrias de poder que amparam as projeções prescritivas dessas "sociedades centrais/modelares" em direção a contextos espaço-temporais "não hegemônicos"; chega-se mesmo

15. Burke e PallaresBurke (2009: 305-306) ensaiam realizar algo nessa direção ao indicarem certo número de "analogias ou afinidades" entre Freyre e a produção pós-colonial. Para além das complexas relações de Freyre com a política colonial portuguesa, pouco sintonizadas com os tipos de preocupação que mobilizam a "agenda pós-colonial", penso que suas formulações acerca das relações raciais no Brasil constituem um obstáculo adicional a essa aproximação. Seja como for, haveria certamente muito mais a explorar a esse respeito (ver, por exemplo: Schneider, 2012 e Valente, 2013). 
16. Conforme pode-se inferir dos programas mencionados há pouco (Eisenstadt, 2000; Schmidt, 2012; Hall, 2011; Mignolo, 2005), ao invés de adstrito aos retratos da modernidade delineados pelos clássicos da sociologia (por exemplo, Marx, Weber e Durkheim) e pelas teorias da modernização que vicejaram em meados do século $X X$, esse quadro de referência também delimita o horizonte de imaginação de lucubrações mais recentes acerca da experiência moderna (Tavolaro, 2014) vide, por exemplo, as formulações de Jürgen Habermas, Niklas Luhmann e Anthony Giddens, dentre outros.

17. Assim é que, em contraste com "contextos modelares", (a) entrelaçamento tempo-espacial (b) indiferenciação social, (c) racionalização societária incompleta, (d) porosidade entre domínios públicos e privados, (e) baixo grau de subjetivação/ individuação, $(f)$ porosidade entre cultura e natureza tornam-se evidências de "desvio" do padrão societário moderno (Tavolaro, 2014). a sugerir que tais assimetrias e projeções ajudam a explicar as imagens de não sincronismo (ou de desvio) com frequência imputadas a tais contextos "não hegemônicos" no quadro da modernidade;

4. ao desafio da validade universal daquelas categorias hegemônicas segue-se a reivindicação de protagonismo em favor de configurações societárias via de regra retratadas como retardatárias ou replicadoras de padrões societários forjados nos cenários modernos ditos "centrais"; em última instância, argumenta-se que tais experiências, ao invés de cópias ou ensaios mais ou menos bem (ou mal)-sucedidos das chamadas "sociedades modernas originárias", representam experiências sociais próprias e, a seu modo, inovadoras no concerto da modernidade; por fim,

5. questiona-se o próprio quadro de referência epistemológico que desde longa data delimita as possibilidades de imaginação sociológica da modernidade e a partir do qual configurações societárias diversas são classificadas de acordo com seus "graus de modernidade".

Nesse enquadramento, a experiência moderna e seu padrão de sociabilidade são retratados por meio dos seguintes termos:

a. tempo progressivo e linear, em crescente desconexão com um espaço esvaziado e dessubstancializado;

b. diferenciação/autonomização de esferas sociais;

c. racionalização societária e secularização;

d. divórcio entre âmbitos privados e esferas públicas;

e. economia emocional organizada em torno da subjetividade centrada;

f. separação ontológica entre a sociedade (cultura) e a natureza (Tavolaro, 2014: 644-645) ${ }^{16}$.

Desafia-se justamente a adoção pura e simples desses referenciais como índices inequívocos da modernidade, bem como a legitimidade de taxionomias que, ao temporalizar configurações societárias diversas com base em seus pretensos "desvios" e "aproximações" em relação a esses referenciais, estabelecem estágios desiguais de sua realização ${ }^{17}$.

Por certo, para o autor de Sobrados e mucambos, desde o século XIX, a sociedade brasileira vinha se alterando não só em seus "modos de viver, de trajar e de 
transportar", mas também em seus "modos de pensar" (Freyre, 1996: 424): em seu entendimento, uma experiência cada vez mais vigiada de perto por olhos estrangeiros implacáveis, com sua "mística de pureza etnocêntrica ou em sua intolerância sistemática do exótico" (Freyre, 1996: 425) ${ }^{18}$, raptada de suas antigas qualidades orientais aclimadas e harmonizadas à natureza americana e à cultura que se forjara do encontro entre portugueses, africanos e indígenas (Freyre, 1996: 424-425). Ainda assim, ao cabo dessas transformações, parecia-lhe que ao invés de mera replicação dos padrões societários da Europa ocidental, essa sociedade adquiria contornos modernos próprios, condizentes com suas especificidades; chegava a tornar-se espelho para outros contextos sociais ${ }^{19}$. Esses e outros aspectos anteriormente discutidos neste artigo oferecem evidências de que as lucubrações de Freyre contemplam cada um dos desafios ao imaginário da modernidade supracitados ${ }^{20}$. Nesse exato sentido, vale sublinhar uma vez mais que, ao contrário das imagens de uma experiência a meio caminho da civilização/modernidade ${ }^{21}$, Freyre retrata o Brasil como "a primeira sociedade moderna construída nos trópicos com característicos nacionais e qualidades de permanência" (Freyre, 2000a: 86; 2000b: 169; 2004: 47; 2010: 205). É verdade que, conforme salientei acima, a fortuna de Freyre é sensível a essa dimensão crítica de sua obra ${ }^{22}$. No entanto, mesmo entre analistas que identificam tal ambição crítica, a vinculação estrita dessa dimensão com suas preocupações a respeito das peculiaridades (socioculturais e naturais) irredutíveis de contextos societários específicos (Larreta \& Giucci, 2007) - com maior frequência o Brasil (Araújo, 1994; Bastos, 2006; Cardoso, 2013; Souza, 2000; Villas-Bôas, 2003) e a América Latina (Baggio, 2012; Crespo, 2003; Schneider, 2012; Valente, 2013) -, dificulta a consideração de suas eventuais contribuições para o discurso sociológico da modernidade, amplamente considerado.

A meu ver, o alcance das formulações de Freyre não se encerra em suas tentativas de reivindicar protagonismo e legitimidade às formas de vida e aos modos de pensar que vicejaram no Brasil nem em sua recusa à adoção da "modernidade europeia" como padrão de medida universal. Para além desses aspectos, suas proposições logram indicar caminhos àqueles desafios dirigidos ao discurso sociológico da modernidade, ou para ser exato, à sua real capacidade para codificar padrões de sociabilidade observados entre as chamadas "experiências societárias não modelares". Esse potencial propositivo inscreve-se no próprio enquadramento epistemológico que delimita suas elaborações: se, por um lado, a conviç̧ão com que retrata o Brasil como "a primeira sociedade moderna nos trópicos" pode, em linhas gerais, confirmar sua aderência à semântica da sociologia da modernidade ${ }^{23}$, por outro, suas imagens da sociedade brasileira assentam-se sobre um referencial que admite a existência sincrônica de variações em cada um dos termos daquele quadro de referência, sem necessariamente dispô-las de maneira sequencial (como se
18. Conforme Freyre, "olhos da Europa", olhos do "Ocidente burguês, industrial, carbonífero, com cujos estilos de cultura, modos de vida, composições de paisagem, chocavamse" (Freyre, 1996: 426-427).

19. Freyre afirma que, "com todas as suas imperfeições, de base econômica e de formas políticas de convivência democrática", - Brasil lograva impor-se "como uma comunidade social" capaz de "servir de exemplo ou estímulo a outras comunidades modernas." (Freyre, 2015: 123).

20. Ver, ademais, Freyre (1941: 194; 1996: 535-536 e 541; 2004: 178).

21. Diagnóstico, aliás, observado em Joaquim Nabuco, Silvio Romero, Euclides da Cunha, Manoel Bomfim, Paulo Prado, para citar apenas alguns dos intérpretes que o precederam.

22. Como, por exemplo, Ricardo B. Araújo (1994: 137).

23. Fato é que suas interpretações a respeito do Brasil e de outras sociedades que lhe servem de parâmetro para retratar a "singularidade brasileira" dedicam atenção a questões relacionadas aos seguintes aspectos: (a) tempo/espaço; (b) 
diferenciação social; (c) racionalização;

(d) relação púbico/ privado;

(e) subjetivação;

(f) relação cultura/ natureza (Tavolaro, 2013; 2016). Larreta e Giucci (2007: 465) chegam mesmo a sustentar que Freyre permanece dependente "do vocabulário das ciências sociais modernas".

fossem momentos ou estágios desiguais de realização). Nesse sentido, (1) ao invés de adotá-lo como modelar da modernidade, Freyre provincianiza o cronótopo no qual o tempo, desvinculado do espaço, assume conotação progressiva e linear, enquanto o espaço adquire acepção abstrata, padronizada e dessubstancializada. Ao assim fazê-lo, as formulações de Freyre abrem caminho para se conceber a existência coeva de outros cronótopos igualmente modernos nos quais, por exemplo, além de entrelaçadas e não lineares, as vivências do passado, do presente e do futuro jamais perdem conexão com espaços plenos de atributos físicos e culturais (Freyre, 1973b: 8).

Disso segue-se igualmente a possibilidade de se conceber a existência coetânea (frise-se, não sucessiva) na modernidade de configurações e experiências societárias nas quais: (2) processos de complexificação e diferenciação constitutivos da modernização fazem-se acompanhar de composições e modalidades variadas de entrelaçamento, contiguidade e influência mútua de esferas sociais diversas (por exemplo, entre o Estado, o mercado, a sociedade civil, a família etc.), ao invés de sua autonomização pura e simples (Freyre, 2000b: 214); (3) a racionalização societária convive com a presença pública e privada de concepções de mundo mágico-religiosas e padrões de conduta não racionalizados, disso derivando formas distintas de secularização (Freyre, 1990: 520-521); (4) as esferas públicas e os âmbitos privados, além de adquirem contornos variados, guardam estreitas relações e influenciam-se mutuamente em diferentes planos da vida social (Freyre, 1996: Xc; (5) ao invés de homogêneas e fixas, as economias emocionais dos indivíduos assentam-se numa pluralidade móvel de identidades (subjetivas e coletivas) que impactam sobre suas condutas públicas e privadas assim como sobre suas autopercepções e visões de mundo (Freyre, 2006: 20-21); por fim (6) nas quais a vida sociocultural é percebida e vivenciada em proximidade estreita com o mundo natural (Freyre, 1976: 67 a 70; 1990: 708).

É fato que as imagens do Brasil delineadas por Gilberto Freyre, não raro envoltas em umas tantas polêmicas e controvérsias, continuam a exigir boa dose de cautela interpretativa. Nesse sentido, sua ambição de elevar a sociedade brasileira à condição de alternativa e modelo a alguns dos principais impasses do mundo contemporâneo (Freyre, 1973: 11 e 116) certamente pode ser desafiada de uma ampla variedade de ângulos. Ainda assim, conforme busquei demonstrar no artigo, suas formulações em torno do tempo-espaço da experiência moderna no Brasil, somadas a seus engajamentos com o imaginário da modernidade, tratam de questões que tocam em preocupações caras ao debate sociológico atual. Crítico contumaz reconhecido do eurocentrismo que em seu tempo predominava nos horizontes de imaginação acerca do país, Freyre oferece insights para uma episteme da modernidade atenta 
a armadilhas etnocêntricas que, de maneiras mais ou menos sutis, continuam a se insinuar sobre as ciências sociais contemporâneas.

Abstract: This article revisits one of the main thesis that crisscrosses Gilberto Freyre's celebrated work, namely, that Brazilian society, itself the outcome of a unique historical formation, succeeded in softening, sometimes even resisting with a great deal of creativity, a set of mental, behavioral, aesthetic as well as institutional standards that imposed themselves from the 19th century onwards. While paying due attention to the connotations of time and space found in the work of Freyre I am especially interested in analyzing how he envisages contemporary Brazil as a successful modern experience of its own rather than an imperfect or distorted version of Western modernity. Last but not least, I will probe into the potential contributions of Freyre's formulations to the sociological discourse of modernity.

Keywords: Gilberto Freyre, Brazilian social thought, modernity, sociological theory.

\section{Referências}

ALMEIDA, J. M. G. Regionalismo e modernismo: as duas faces da renovação cultural dos anos 20. In: KOSMINSKY, E. V.; LÉPINE, C.; PEIXOTO, F. A. (Orgs.). Gilberto Freyre em quatro tempos. Bauru; São Paulo: Edusc; Editora Unesp, 2003.

ANDERSON, B. Imagined communities. London: Verso, 1991.

ANDRADE, M. C. O espaço geográfico na obra de Gilberto Freyre. In: KOSMINSKY, E. V.; LÉPINE, C.; PEIXOTO, F. A. (Orgs.). Gilberto Freyre em quatro tempos. Bauru; São Paulo: Edusc; Editora Unesp, 2003.

ARAÚJO, R. B. Guerra e Paz. Rio de Janeiro: Editora 34, 1994.

BAKHTIN, M. Questões de literatura e de estética: A teoria do romance. São Paulo: Editora Unesp; Hucitec, 1988.

BAGGIO, K. Iberismo, hispanismo e latino-americanismo no pensamento de Gilberto Freyre. Investigaciones Socio Históricas Regionales, Año 2, n. 2, p. 109-131, 2012.

BASTOS, E. R. As criaturas de prometeu. São Paulo: Global, 2006.

BERGMANN, W. The problem of time in sociology: An overview of the literature on the state of theory and research on the "Sociology of Time", 1900-82. Time \& Society, v. 1, n. 1, p. 81-134, 1992.

BERMAN, M. Tudo que é sólido desmancha no ar. São Paulo: Companhia das Letras, 1986. 
Burke, P.; PAllares-BURKe, M. L. Repensando os trópicos. São Paulo: Editora Unesp, 2009.

CARDOSO, F. H. Pensadores que inventaram o Brasil. São Paulo: Companhia das Letras, 2013.

CASTELLS, M. The rise of network society. Massachusetts: Blackwell Publishers Ltd., 1999.

CHAKRABARTY, D. Provincializing Europe. Princeton: Princeton University Press, 2000.

CHATTERJEE, P. La nación en tiempo heterogêneo. Buenos Aires: Siglo XXI, 2008.

CRESPO, R. A. Gilberto Freyre e suas relações com o universo cultural hispânico. In: KOSMINSKY, E. V.; LÉPINE, C.; PEIXOTO, F. A. (Orgs.). Gilberto Freyre em quatro tempos. Bauru; São Paulo: Edusc; Editora Unesp, 2003.

CUNHA, E. Os sertões: campanha de canudos. Rio de Janeiro: Francisco Alves, 1981.

DOMINGUES, J. M. Global modernization, "coloniality" and a critical sociology for contemporary Latin America. Theory, Culture \& Society, v. 26, n. 1, p. 112-133, 2009.

DUSSEL, E. Europa, modernidade e eurocentrismo. In: LANDER, E. (Org.). A colonialidade do saber. Buenos Aires: Clacso, 2005.

EISENSTADT, S. N. Modernity and modernization. Sociopedia.isa, p. 1-15, 2010.

—. Multiple modernities. Dædalus, v. 129, n. 1, p. 1-29, 2000.

FREYRE, G. Interpretação do Brasil. São Paulo: Global Editora, 2015 [1944].

—. O luso e o trópico. São Paulo: É Realizações, 2010 [1961].

—. Tempo morto e outros tempos. São Paulo: Global, 2006 [1975].

—. Nordeste. São Paulo: Global, 2004 [1937].

—. Americanidade e latinidade da América Latina: crescente interpenetração e decrescente segregação. In: FREYRE, G. Americanidade e latinidade da América Latina e outros textos afins. Brasília; São Paulo: EdUnB; Imprensa Oficial do Estado, 2003a [1942].

— . A propósito da política cultural do Brasil na América. In: FREYRE, G. Americanidade e latinidade da América Latina e outros textos afins. Brasília; São Paulo: EdUnB; Imprensa Oficial do Estado, 2003b [1942]. 
- Interamericanismo. In: FREYRE, G. Americanidade e latinidade da América Latina e outros textos afins. Brasília; São Paulo: EdUnB; Imprensa Oficial do Estado, 2003c [1942].

- Americanismo e hispanismo. In: FREYRE, G. Americanidade e latinidade da América Latina e outros textos afins. Brasília; São Paulo: EdUnB; Imprensa Oficial do Estado, 2003d [1942].

_. Casa-grande \& senzala. Rio de Janeiro: Record, 2000a [1933].

_. Novo mundo nos trópicos. Rio de Janeiro: Topbooks, 2000b [1963/1971].

—. Prefácio à primeira edição em língua portuguesa. In: FREYRE, G. Novo mundo nos trópicos. Rio de Janeiro: Topbooks, 2000c [1969].

—. Sobrados e mucambos. Rio de Janeiro: Record, 1996 [1936].

_. Ordem e progresso. Rio de Janeiro: Record, 1990 [1959].

_. Manifesto regionalista. Maceió: EdUfal, 1976 [1952].

- O brasileiro entre os outros hispanos. Rio de Janeiro; Brasília: José Olympio; Instituto Nacional do Livro, 1975a.

- On the Iberian concept of time. In: FREYRE, G. O brasileiro entre os outros hispanos. Rio de Janeiro; Brasília: José Olympio; Instituto Nacional do Livro, 1975b [1963].

— Além do apenas moderno. Rio se Janeiro: Livraria José Olympio Editora, 1973.

. Como e porque sou e não sou sociólogo. Brasília: EdUnB, 1968.

—. Região e tradição. Rio de Janeiro: Livraria José Olympio Editora, 1941.

GIDDENS, A. As conseqências da modernidade. São Paulo: Editora Unesp, 1991.

GÖLE, N. Snapshots of Islamic modernities. Dædalus, v. 129, n. 1, p. 91-117, 2000.

GUMBRECHT, H. U. Nosso amplo presente. São Paulo: Editora Unesp, 2015.

_. Produção de presença: o que o sentido não conseguiu transmitir. Rio de Janeiro: Contraponto; Editora PUC-Rio, 2010.

—. Modernização dos sentidos. São Paulo: Editora 34, 1998.

HABERMAS, J. O discurso filosófico da modernidade. Lisboa: Dom Quixote, 1990. 
HARVEY, D. The condition of postmodernity. Cambridge: Blackwell, 1995.

HALL, S. Da diáspora: identidades e mediações culturais. Belo Horizonte: Editora UFMG, 2011.

KOSMINSKY, E. V.; LÉPINE, C.; PEIXOTO, F. A. (Orgs.). Gilberto Freyre em quatro tempos. Bauru; São Paulo: Edusc; Editora Unesp, 2003.

KOSELLECK, R. "Modernidade": sobre a semântica dos conceitos de movimento na modernidade. In: KOSELLECK, R. Futuro passado. Rio de Janeiro: Contraponto; Editora PUC-Rio, 2006a.

__ . "Espaço de experiência" e "horizonte de expectativa": duas categorias históricas. In: KOSELLECK, R. Futuro passado: contribuição à semântica dos tempos históricos. Rio de Janeiro: Contraponto, Ed. PUC-Rio, 2006b.

LARRETA, E.; GIUCCI, G. Gilberto Freyre: uma biografia cultural. Rio de Janeiro: Civilização Brasileira, 2007.

LEHMANN, D. Gilberto Freyre: a reavaliação prossegue. Horizontes Antropológicos, n. 29, p. 369-385, 2008.

LIMA, N. T. Um sertão chamado Brasil. São Paulo: Hucitec Editora, 2013.

LUHMANN, N. The future cannot begin: temporal structures in modern society. Social Research, v. 43, n. 1, p. 130-152, 1976.

MIGNOLO, W. The idea of Latin America. Oxford: Blackwell, 2005.

_. Local histories/global designs. Princeton: Princeton University Press, 2000.

NABUCO, J. O abolicionismo. São Paulo: Publifolha, 2000.

PALLARES-BURKE, M. L. Gilberto Freyre - um vitoriano dos trópicos. São Paulo: Editora Unesp, 2005.

PRADO, P. Retrato do Brasil. São Paulo: Companhia das Letras, 2012.

QUIJANO, A. Colonialidade do poder, eurocentrismo e América Latina. In: LANDER, E. (Org.). A colonialidade do saber. Buenos Aires: Clacso, 2005.

ROMERO, S. Compêndio de história da literatura brasileira. Rio de Janeiro: Imago Editora, 2001. 
SANTOS, A. C. As naturezas de Freyre: natureza e ecologia em "Nordeste" (1937) de Gilberto Freyre. Dissertação (Mestrado em Sociologia) - Departamento de Sociologia, Instrituto de Filosofia e Ciências Humanas (IFCH), Universidade Estadual de Campinas (Unicamp), Campinas, 2008.

SCHMIDT, V. Conceptualizing global modernity. A tentative sketch. Working Paper Series, Department of Sociology, National University of Singapore, p. 1-52, 2012.

- Modernidades múltiplas ou variedades da modernidade? Revista de Sociologia e Política, n. 28, p. 147-160, 2007.

SCHNEIDER, A. L. Iberismo e luso-tropicalismo na obra de Gilberto Freyre. História da Historiografia, n. 10, p. 75-93, 2012.

SOUZA, J. Gilberto Freyre e a singularidade cultural brasileira. Tempo social, v. 12, n. 1, p. 69-100, 2000.

TAVOLARO, S. B. F. Imagens de uma outra modernidade: Gilberto Freyre e o espaço-tempo latino-americano. Política \& Sociedade, v. 15, n. 34, p. 196-231, 2016.

. A tese da singularidade brasileira revisitada: desafios teóricos contemporâneos. Dados, v. 57, n. 3, p. 633-673, 2014.

. Gilberto Freyre e nossa "Modernidade Tropical": entre a originalidade e o desvio. Sociologias, v. 15, n. 33, p. 282-317, 2013.

TUNA, G. Gilberto Freire: entre tradição \& ruptura. São Paulo: Editorial Cone Sul, 2000.

VALENTE, L. F. Americanidade e Latinoamericanidade na obra de Gilberto Freyre. Antares: Letras e Humanidades, v. 5, n. 10, p. 105-114, 2013.

VILLAS-BÔAS, G. Mudança provocada. Rio de Janeiro: Editora FGV, 2006.

- Casa grande e terra grande, sertões e senzala: a sedução das origens. In: KOSMINSKY, E. V.; LÉPINE, C.; PEIXOTO, F. A. (Orgs.). Gilberto Freyre em quatro tempos. Bauru; São Paulo: Edusc; Editora Unesp, 2003.

WITTROCK, Björn. Modernity: one, none or many? European origins and modernity as a global condition. Dædalus, v. 129, n. 1, p. 31-60, 2000. 
Outras fontes

BASTOS, E. R. Os autores brasileiros e o pensamento hispânico. Anais do XXII Encontro anual da Anpocs, 1998. <http://portal.anpocs.org/portal/index.php?option=com_docman\&task=doc_view\&gid=5111\&ltemid=359>. Acesso em: 15 Ago. 2014.

FREITAS, I. M. A Brasil e as Américas em Gilberto Freyre: das veias abertas pela colonização aos veios abertos para o futuro. Anais do XXIX Congresso Latinoamericano de Sociologia, 2013. In: <http://actacientifica.servicioit.cl/biblioteca/gt/GT17/ GT17_MendesFreitas.pdf>. Acesso em: 20 Ago. 2014. 